\title{
The effect of CD14 and TLR4 gene polimorphisms on asthma phenotypes in adult Turkish asthma patients: a genetic study
}

\author{
Füsun Şahin ${ }^{*}$, Pınar Yıldı ${ }^{1}$, Ayşegül Kuskucu ${ }^{2}$, Mert Ahmet Kuskucu ${ }^{3}$, Nilgün Karaca $^{4}$ and Kenan Midilli ${ }^{3}$
}

\begin{abstract}
Background: Endotoxins stimulate T helper 1 cell maturation and send a negative signal to T helper 2 polarisation. This causes a decrease IgE levels and prevents atopy (Hygiene hypothesis). It is shown that this response is under genetic control by polymorphisms in CD14 and TLR4 genes in some researchs. We aimed to investigate the effects of genetic variants of CD14 (-) and TLR4 (Asp299Gly, Thr399lle) genes on asthma phenotypes in adults with asthma.
\end{abstract}

Methods: Asthma patients $(n=131)$ and healthy control cases $(n=75)$ were included in the study. Relations between CD14 C-159 T, TLR4 299 and TLR4 399 genotypes and duration of asthma history of allergic rhinitis-dermatitis, total IgE, eosinophil, skin prick test, forced expiratory volume 1 (FEV1) and severity of disease were evaluated. Real time PCR (RT-PCR) was used for genotyping.

Results: For CD14-159, presence of the $C$ allele $(C C+C T)$ was more frequent among those with low median log (logarithm) IgE levels, but no statistically significant difference in all asthma group $(p=0.09)$. C allele was significantly correlated with low total IgE levels and T allele with high total IgE levels in atopics $(p=0.04)$. CC $+C T$ genotype was more frequent in moderate and severe asthma group in atopics ( $p=0.049)$. TLR4 299 and TLR4 399 genotypes and asthma phenotypes were not found to be significantly correlated ( $p>0.05)$.

Conclusions: Total lgE levels were found to be low among patients with the $C C+C T$ genotype, and high among patients with the $\Pi$ genotype contrary to the results of many other studies, which is therefore an important finding. Another important finding was that the $\mathrm{C}$ allele is a risk factor for moderate and severe asthma.

Keywords: Asthma, Atopy, Gen polymorphism, CD14, TLR4, Total IgE, Eosinophil

\section{Background}

Asthma is a complex disease in which pathogenesis is related to both genetic and environmental factors [1]. In 1989, Strachan [2] put "hygiene hypothesis", which proposed that reduced exposure to infectious microorganisms in childhood leads to an increased risk of allergic disease in later years. It is thought that bacteria stimulate $\mathrm{T}$ helper 1 (Th1) maturation, inhibite T helper 2 (Th2) polarisation and ultimately decrease IgE levels. Innate immunity utilizes the Toll-like receptor (TLR) family to identify pathogens. TLRs are expressed on the cell

\footnotetext{
* Correspondence: fusunsahin19700@hotmail.com

'Department of Chest Diseases, Yedikule Chest Diseases and Surgery Training and Research Hospital, Zeytinburnu/Istanbul, 34760, Turkey

Full list of author information is available at the end of the article
}

surface and initiate immune defence by recognising structures specific to microorganisms, such as lipopolysaccharide (LPS) [3]. Pathogens also contain complexes called "pathogen associated molecular patterns (PAMPs)", which are not present in the host [4]. During an infection, macrophages recognise PAMPs via TLRs. Dendritic cell activation occurs due to the stimulation of TLRs, enabling communication between peripheral and lymphatic tissues; in turn $\mathrm{T}$ cells are activated, which is the most important component of the acquired immune system $[5,6]$. Numerous studies have implicated TLR2, TLR4 and TLR9 in the pathogenesis of asthma or atopy [7-9]. CD14 is a multifunctional receptor on macrophages and monocytes that binds endotoxin and other bacterial wall components. CD14 promotes immune activation by facilitating 
the presentation of LPS to TLR4 [10], which triggers interleukin-(IL)-12 and IL-18 signalling and interferongamma production. As a result a shift to Th1 occurs and atopy is prevented. In recent years it was shown that this response is under genetic control and is specifically determined by polymorphisms in the CD14. The TLR4 single nucleotide polymorphisms A896G and C1196T (result in the amino acid substitutions Asp299Gly $\rightarrow$ RefSNP ID: rs4986790 and Thr399lle $\rightarrow$ RefSNP ID: rs4986791, respectively) and affect the extracellular domain of the TLR4 receptor $[7,11]$. These two polymorphisms modify the receptor's response to endotoxin, which is an important trigger of asthma [7]. Similarly, the CD14 polymorphism C159 T (RefSNP ID: rs2569190) has been shown to influence serum IgE levels and skin prick test responses to allergens $[7,12]$. Allergic disease may emerge through exposure to endotoxins, although responsiveness may differ according to genetic factors $[11,12]$. In this way the effect of endotoxins may vary according to the atopic condition of the host. As a result it is thought that the effect of the CD14 -159 genotype (CC, TT or CT) on the asthma phenotype (in terms of total IgE levels) may also vary and numerous studies have been conducted to investigate the relationship between CD14 variants and total IgE levels [13]. In the present study, we investigated the effects of genetic variants of the CD14(C-159 T) and TLR4 (Asp299Gly and Thr399Ile) polymorphisms on adult asthma phenotypes specifically the severity of disease, total IgE concentrations and eosinophil counts. This study is important because it is the first to evaluate together with the effects of both CD14 and TLR4 genetic variants on disease in adult patients with asthma in Turkey.

\section{Methods}

\section{Study subjects}

Patients with asthma $(\mathrm{n}=131)$ and healthy controls $(\mathrm{n}=75)$ who presented to the Third Chest Diseases Outpatient Clinic at the Yedikule Chest Diseases and Surgery Training and Research Hospital between January 2010 and December 2011 were included in this study. A power analysis was performed for each gene polymorphism (CD14 -159, TLR4 299, TLR4 399) at the beginning of the study (to determine the necessary sample size). We determined the allele frequencies of all polymorphisms (CD14 -159, TLR4 299, TLR4 399) according to the results of the studies from our region $[13,14]$ and a meta-analysis (that included European, East Asian and Indian populations) [15]. The allele frequency of CD14 C-159 $\mathrm{T}$ was approximately $75 \%$ in the asthma group, $53 \%$ in the control group. The power analysis was performed according to these values. For the C-159 T polymorphism, the required sample size was 74 for each group (Approximate Test). The allele frequencies for TLR4 299 and TLR4 399 were approximately $20 \%$ in the asthma group, $5 \%$ in the control group, an again the reguired sample size was determined to be 70 for each group (Approximate Test). The number of patients in our study met these criteria.

Asthma was diagnosed according to the Global Initiative for Asthma (GINA) guidelines in patients with recurrent dyspnoea, wheezing attacks and positive airway reversibility test $(12 \%$ or $>200 \mathrm{~mL}$ increase in FEV1 after $400 \mu \mathrm{g}$ salbutamol inhalation) [16]. Patients who had an attack in the previous month and/or were treated with systemic steroids, took specific allergen immunotherapy, had a personal or family history of tuberculosis, or had active pathology or sequelae upon chest X-ray examination were excluded. The control group was composed of healthy individuals with no personal or family history of atopy or tuberculosis. Ninety six patients with allergic symptoms or a history of allergy and who showed a positive reaction to at least one allergen on skin prick testing were classified as having atopic asthma, and 35 patients with no allergic symptoms, no personal history and negative skin test results were classified as having nonatopic asthma. This study was performed in accordance with the principles of the Declaration of Helsinki (2008) and approved by the ethics committee of Yeditepe University. Written and signed informed consent was obtained from all participants.

\section{Measurements}

Spirometric evaluations were performed with a MasterScope-PC (Jaeger, Germany), total IgE levels were measured with a Unicel D $\times$ I 800 analyser (Beckman Coulter, (US) and eosinophil counts were determined using an ABX Pentra 120 system (Impedance\&Optical, Minnesota, USA). All patients with asthma underwent a skin prick test with 15 standard aero-allergens and five food allergens (ALK-Abellò, Hørsholm, Denmark). Oedema of $>3 \mathrm{~mm}$ was accepted as positive.

\section{Genotyping}

A total of 131 EDTA containing blood samples were collected from patients with asthma and stored at $-80^{\circ} \mathrm{C}$ until nucleic acid purification. Residual EDTA containing blood samples collected for routine biochemistry tests were used as the control group. Nucleic acids were isolated from these samples using a commercial genomic DNA extraction kit (Thermo Scientific, MA, USA).

The Rotor-Gene Q 5plex high resolution melting (HRM) platform and Rotor-Gene 6000 series software v1.7 (Qiagen, Hilden, Germany) were used for real time PCR amplification and HRM analysis. 5x Hot Fire Pol Evagreen HRM mix (Solis BioDyne, Tartu, Estonia) used for PCR amplification and PCR reactions were performed in a $20 \mu \mathrm{L}$ final volume containing $5 \mu \mathrm{L}$ of purified genomic DNA. $0.1 \mathrm{mM}$ of primers (Table 1) used 
Table 1 Primers used in this study

\begin{tabular}{|c|c|c|}
\hline Primer name & Sequence & References \\
\hline TLR_299_F & $\begin{array}{l}\text { TGA AGA ATT CCG ATT AGC } \\
\text { ATA CTT AGA }\end{array}$ & {$[17]$} \\
\hline TLR_299_R & $\begin{array}{l}\text { CTT TCA ATA GTC ACA CTC } \\
\text { ACC AG }\end{array}$ & In this study \\
\hline TLR_399_F & $\begin{array}{l}\text { TGA GTT TCA AAG GTT GCT } \\
\text { GTT CTC }\end{array}$ & [17] \\
\hline TLR_399_R & $\begin{array}{l}\text { GTT TGA ACT CAT GGT AAT } \\
\text { AAC ACC }\end{array}$ & In this study \\
\hline CD14-159_F & GCCTCTGACAGTITATGTAATC & [14] \\
\hline CD14-159_R & GTGCCAACAGATGAGGTTCAC & [14] \\
\hline
\end{tabular}

for amplification. Amplification was performed $95^{\circ} \mathrm{C}$ for 10 minutes for initial denaturation followed by 30 cycles at $95^{\circ} \mathrm{C}$ for 10 seconds, $53^{\circ} \mathrm{C}$ for 45 seconds and $72^{\circ} \mathrm{C}$ for 45 seconds. After amplification, denaturation was performed from $72^{\circ} \mathrm{C}$ to $90^{\circ} \mathrm{C}$ for HRM analysis. Representative samples of genotypes were confirmed by DNA sequencing for TLR4 polymorphisms and via the restriction fragment length polymorphism (RFLP) method for the CD14 polymorphism. Representative samples were also used controls for further tests (Table 1) [14,17].

\section{Statistical analysis}

Statistical analyses were performed using the SPSS 16 package software (SPSS Inc., Chicago, IL, USA). Patient demographics and disease characteristics were summarised using descriptive statistics. All numeric data were expressed as the mean \pm standard deviation, and non-numeric data as frequencies and percentages. Statistical differences between group means were analysed using Student's t-test. One- way analysis of variance (ANOVA) was used to compare means among more than two groups, and Tukey's HSD test was used in the post-hoc analysis as necessary. A chi-square test was used to determine whether allele and genotype frequencies in the asthma and healthy control groups deviated from the Hardy-Weinberg equilibrium. The chi-square

Table 2 Characteristics of asthma and control groups

\begin{tabular}{|c|c|c|c|}
\hline Characteristics & Number of cases ( $n$ ) & Mean (Standart deviation) & Range \\
\hline Age (Year) & 131 & $36(12.42)$ & $18-68$ \\
\hline Atopic & 96 & $31(8.72)$ & $18-57$ \\
\hline Non-atopic & 35 & $52(6.57)$ & $42-68$ \\
\hline Control & 75 & $43(7.68)$ & $23-65$ \\
\hline Female (Total) & 96 & & \\
\hline Atopic & 63 & & \\
\hline Non-atopic & 30 & & \\
\hline Control & 50 & & \\
\hline Male (Total) & 35 & & \\
\hline Atopic & 33 & & \\
\hline Non-atopic & 5 & & \\
\hline Control & 25 & & \\
\hline Duration of asthma (Year) & 131 & $4.52(5.28)$ & $0-35$ \\
\hline \multicolumn{4}{|l|}{ FEV1 (\%) } \\
\hline Asthma & 131 & $68.60(12.67)$ & $37-97$ \\
\hline Control & 75 & $95.70(14.56)$ & $90-115$ \\
\hline \multicolumn{4}{|l|}{ Total lgE (kU/l) } \\
\hline Asthma & 131 & $175.77(220.28)$ & $4-986$ \\
\hline Control & 75 & $45.32(30.25)$ & $5-89$ \\
\hline \multicolumn{4}{|l|}{ Eosinophil (\%) } \\
\hline Asthma & 131 & $3.39(2.9)$ & $0-14$ \\
\hline Control & 75 & $1.10(0.5)$ & $0-3$ \\
\hline \multicolumn{4}{|l|}{ Skin prick test (Asthma) } \\
\hline Positive & 96 & & \\
\hline Negative & 35 & & \\
\hline
\end{tabular}

FEV1: Forced expiratory volume 1. 
test was used for non-numeric data. A p value of $<0.05$ was accepted as statistically significant.

\section{Results}

Characteristics of the asthma and control groups are shown in Table 2. No significant differences were observed among the CD14 -159, TLR4 299, and TLR4 399 genotype distributions between the asthma and control groups $(p>0.05)$. The allele and genetic variant frequencies of the two groups are given in Table 3. CD14 C159 T, TLR4 299 and TLR4 399 genotypes, total IgE levels, eosinophil counts, and FEV1 were evaluated according to severity of disease and atopy status (Tables 4 and 5). To determine factors affecting total IgE levels, we performed a logistic regression analysis using the backward stepwise method for variable selection based on the likelihood ratio. Because the median IgE level in the asthmatic patients was $98 \mathrm{kU} / \mathrm{L}$, this value was used as the threshold for calculations in the logistic regression analysis (Table 6). A significant correlation was found between IgE levels and allergic dermatitis, eosinophil counts, and skin prick test results.

Total IgE levels were converted to a normal distribution using logarithmic (log) transformation. No significant difference was observed when individually comparing the median $\log$ IgE (according to 1.99) among patients with the CC, CT, TT genotypes of the CD14C-159 T polymorphism $(p=0.08)$; in the asthma group, presence of the $\mathrm{C}$ allele $(\mathrm{CC}+\mathrm{CT})$ was more frequent among those with

Table 3 Genotype-allele distribution in asthma and control group

\begin{tabular}{|c|c|c|c|}
\hline Genotypes/Alleles & $\begin{array}{l}\text { Asthma patients } \\
\text { n (\%) }\end{array}$ & $\begin{array}{l}\text { Control group } \\
\mathrm{n}(\%)\end{array}$ & p \\
\hline \multicolumn{4}{|l|}{ CD14-159 } \\
\hline CC & $26(19.3)$ & $15(19.4)$ & $0.99(\mathrm{NS})^{*}$ \\
\hline$C T$ & $63(49.2)$ & $36(49.2)$ & \\
\hline$\pi$ & $42(31.5)$ & $24(31.4)$ & \\
\hline$C C+C T$ (C allele) & 115(43.9) & $66(44)$ & \\
\hline$\Pi$ T (T allele) & $147(56.1)$ & $84(56)$ & \\
\hline \multicolumn{4}{|l|}{ TLR4 299} \\
\hline AA & $122(93.1)$ & $71(94.7)$ & $0.77(\mathrm{NS})^{*}$ \\
\hline GA & $9(6.9)$ & $4(5.3)$ & \\
\hline A allele & $253(96.6)$ & $146(97.3)$ & \\
\hline G allele & $9(3.4)$ & $4(2.7)$ & \\
\hline \multicolumn{4}{|l|}{ TLR4 399} \\
\hline CC & $120(91.6)$ & $71(94.7)$ & $0.58(\mathrm{NS})^{*}$ \\
\hline$C T$ & $11(8.4)$ & $4(5.3)$ & \\
\hline C allele & $251(95.8)$ & $146(97.3)$ & \\
\hline T allele & $11(4.2)$ & $4(2.7)$ & \\
\hline
\end{tabular}

NS: Not significant.

*Chi-square test. low IgE levels, but no statistically significant difference was detected $(\mathrm{p}=0.09$, Figure $1 \mathrm{~A})$. Patients in the asthma group were classified as either atopic and non-atopic according to the results of the skin prick test and history of atopic rhinitis-dermatitis A significant association was observed between skin prick test positivity and high total IgE levels and eosinophil counts. Moderate asthma was more frequent in the atopic group and severe asthma was found in the non-atopic group; FEV1 was lower in both the atopic and non-atopic groups. In atopic patients, there was a significant association between the median $\log \operatorname{IgE}$ (according to 1.99) and the presence of the $\mathrm{C}$ allele ( $\mathrm{p}=$ 0.04 , Figure 1B). As a result, it was found that the $\mathrm{C}$ allele was significantly correlated with low total IgE levels and that the $\mathrm{T}$ allele was significantly correlated with high total IgE levels. However, among all asthma patients, no significant association was observed between the severity of asthma and $\mathrm{CC}+\mathrm{TT}$ and $\mathrm{TT}(\mathrm{p}=0.10$, Figure $2 \mathrm{~A})$. In the atopy group, a significant association was also observed between the severity of asthma and $\mathrm{CC}+\mathrm{TT}$ and TT genotypes $(\mathrm{p}=0.049$, Figure $2 \mathrm{~B})$. Specifically, the $\mathrm{C}$ allele was significantly more frequent in the moderate and severe asthma groups.

The TLR4 299 and TLR4 399 genotypes were not significantly associated with asthma phenotype $(\mathrm{p}>0.05)$. Heterozygous TLR4 genotypes (TLR4 A896G and TLR4 C1196T polymorphisms) were more frequent in the moderate asthma group, but this association was not statistically significant. No significant difference was observed between the atopic and non-atopic groups.

\section{Discussion}

The CD14 gene is present in the major susceptibility region (5q31-33) for atopy and asthma $[17,18]$. Studies investigating the relationship between the $\mathrm{CD} 14$ gene and atopy and asthma have revealed conflicting results. First, Baldini et al. [12] described several single nucleotide polymorphisms in the CD14 gene, which is a receptor with high affinity for LPS. The polymorphisms described were found to affect the binding affinity for Sp1, -2 , and -3 transcription factors at the $\mathrm{GC}$ box in vitro, thus altering the expression of CD14. They also detected a C-T substitution in the promoter region of the gene (the CD14$159 \mathrm{~T}$ polymorphism) and higher CD14 levels and low skin test sensitivity in TT homozygotes [12]. The CD14 $\mathrm{C}-159 \mathrm{~T}$ polymorphism involves a $\mathrm{C} \rightarrow \mathrm{T}$ nucleotide substitution, located $-260 \mathrm{bp}$ from the translation start site and $-159 \mathrm{bp}$ from the transcription start site, which alters CD14 promoter activity in vitro by decreasing the affinity of Sp protein binding and thus enhancing transcriptional activity [19]. As a result, the CD14 C-159 T promoter polymorphism was associated with serum CD14 levels $[12,20]$ as well as the phenotypes of patients with allergy $[18,21]$. In a meta-analysis reviewing studies of Asian 
Table 4 Genotypic- phenotypic features in all asthma patients with mild, moderate and severe asthma

\begin{tabular}{|c|c|c|c|c|c|c|c|}
\hline & \multirow{2}{*}{\multicolumn{3}{|c|}{$\frac{\text { All asthma patients }}{\text { (Standart deviation) }}$}} & \multirow[t]{4}{*}{$p$} & \multirow{4}{*}{$\begin{array}{l}\text { Atopic } \\
\text { Asthmatics (Standart deviation) } \\
(n=96)\end{array}$} & \multirow{3}{*}{$\begin{array}{l}\text { Non-atopic } \\
\text { Asthmatics (Standart deviation) } \\
(n=35)\end{array}$} & \multirow[t]{4}{*}{$p$} \\
\hline & & & & & & & \\
\hline & \multicolumn{3}{|c|}{ 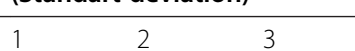 } & & & & \\
\hline & $(n=19)$ & $(n=78)$ & $(n=34)$ & & & & \\
\hline \multirow[t]{2}{*}{ FEV1 (\%) } & 88 & 72 & 51 & $<0.001$ & 71 & 62 & $<0.001$ \\
\hline & $(6.7)$ & $(4.2)$ & $(6.2)$ & & (12) & (13) & \\
\hline \multirow[t]{2}{*}{ Eosinophil (\%) } & 3.25 & 4.02 & 3.61 & $<0.001$ & 3.84 & 2.2 & 0.008 \\
\hline & (3) & (3.35) & $(2.5)$ & & $(3.2)$ & (1.3) & \\
\hline \multirow[t]{2}{*}{ Total lgE (kU/L) } & 170 & 240 & 199 & 0.006 & 223 & 47 & $<0.001$ \\
\hline & (156) & (255) & (244) & & $(240)$ & (37) & \\
\hline \multirow[t]{2}{*}{ Log IgE median } & 1.9 & 2.02 & 1.7 & 0.006 & 2.1 & 1.5 & $<0.001$ \\
\hline & $(0.5)$ & $(0.6)$ & $(0.6)$ & & $(0.5)$ & $(0.4)$ & \\
\hline \multicolumn{8}{|l|}{ CD14-159 } \\
\hline $\mathrm{CC}$ & 1 & 14 & 5 & 0.27 & 20 & 6 & 0.62 \\
\hline CT & 5 & 31 & 7 & & 43 & 19 & \\
\hline TT (T Allele) & 9 & 21 & 3 & & 33 & 10 & \\
\hline CC+CT (CAllele) & 6 & 45 & 12 & 0.10 & 63 & 25 & 0.68 \\
\hline \multicolumn{8}{|l|}{ TLR4 299} \\
\hline $\mathrm{AA}$ & 14 & 60 & 14 & 0.45 & 88 & 34 & 0.44 \\
\hline GA & 1 & 6 & 1 & & 8 & 1 & \\
\hline \multicolumn{8}{|l|}{ TLR4 399} \\
\hline $\mathrm{CC}$ & 14 & 58 & 14 & 0.23 & 86 & 34 & 0.29 \\
\hline $\mathrm{CT}$ & 1 & 8 & 1 & & 10 & 1 & \\
\hline
\end{tabular}

Comperative Features in Atopic and Non-atopic Asthmatics.

1: Mild asthma; 2: Moderate asthma; 3: Severe asthma. FEV1: Forced expiratory volume 1. Log lgE: Logarithm lgE.

Significant $\mathrm{p}$ value is shown with black boldface.

population and children, the TT and CT genotypes were correlated with decreased atopic asthma risk compared to CC $[15,22]$. On the other hand in some studies have reported that the $\mathrm{C}$ allele [23] was a risk factor and CC genotype was found to be correlated with positive skin prick test [24]. Another meta-analysis reported that among individuals with TT genotypes exposure to low levels of endotoxins was protective for asthma, but high levels of endotoxin increased the risk of asthma. Conversely, in individuals carrying the $\mathrm{C}$ allele exposure to high levels of endotoxin had a protective effect [25]. In another study, increasing endotoxin exposure was associated with a reduced risk of allergic sensitisation but and increased risk of non-atopic wheezing in children with the $\mathrm{CC}$ genotype at position -159 of the CD14 gene [26]. In our study the distributions of the CD14 genotypes (CC, $\mathrm{CT}, \mathrm{TT})$ did not differ significantly between the asthma and control groups. Unlike the studies mentioned no significant correlation was observed between the CD14 genotype and positive skin test, however the CD14 genotype was correlated with the level of total IgE and severity of disease. Studies investigating the correlation between total IgE levels and the CD14 genotype revealed conflicting results. In one study the CD14-159 genotype was correlated with total IgE levels and this correlation was reported to vary according to varying levels of endotoxin exposure [27]. In individuals with the CC genotype both clinical signs of atopic disease and skin test positivity with high serum IgE levels were encountered more frequently $[18,28,29]$. Similarly in a study of children in India the CD14 C-159 T CC genotype was strongly associated with atopic asthma and serum IgE [30]. Saçkesen et al. [13] reported that the $\mathrm{T}$ allele was correlated with low levels of total IgE in children with atopic asthma. The association between $\mathrm{C}-159 \mathrm{~T}$ genotype and allergic sensitisation depends on the level of exposure to endotoxins: TT homozygotes are protected at low levels of exposure and at risk at high levels [29]. These findings suggest an antagonistic interaction between the environment and C-159 $\mathrm{T}$ as a determinant of allergic sensitization: the $\mathrm{T}$ allele could be either a protective factor or a risk factor, depending on the degree of exposure to environmental microbial products [29]. In other studies C-159 T alleles were not found to be correlated with asthma and atopy (e.g.allergic rhinitis) in children and adults [31-34]. In a study no correlation between C-159 $\mathrm{T}$ and serum IgE levels was found [35]. 
Table 5 Genotypic-phenotypic features in atopic and non-atopic patients with mild, moderate and severe asthma

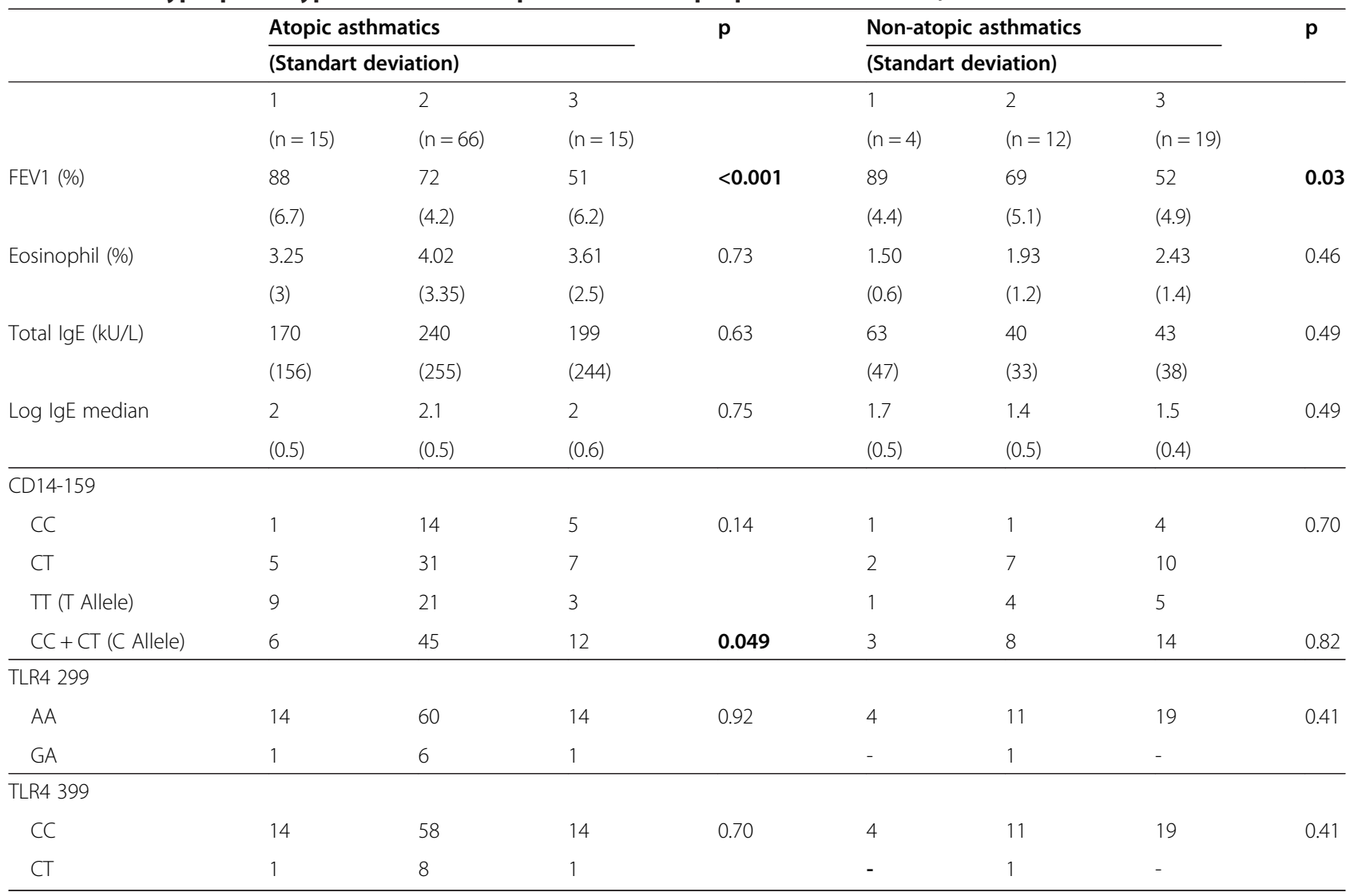

1: Mild asthma; 2: Moderate asthma; 3: Severe asthma. FEV1: Forced expiratory volume 1. Log lgE: Logarithm IgE.

Significant $\mathrm{p}$ value is shown with black boldface.

Unlikely there was no significant association between the medianlog IgE concentration and asthma group (atopic and non-atopic) regarding CD14 genotype distribution in our study, although a significant difference was observed within the atopic asthma group for median log IgE levels

Table 6 Logistic regression analysis for total IgE level >98 kU/L

\begin{tabular}{llll}
\hline & \multicolumn{3}{l}{ Multivariate } \\
\hline Age & - & $95 \% \mathrm{Cl}$ & $\mathrm{p}$ \\
Sex & - & - & - \\
Allergic rhinitis & - & - & - \\
Allergic dermatitis & 8.79 & $1.81-46.88$ & - \\
Severity of asthma & - & - & $\mathbf{0 . 0 0 7}$ \\
Eosinophil (\%) & 1.54 & $1.23-1.93$ & - \\
Skin-prick test reactivity & 4.90 & $1.64-14.62$ & $\mathbf{0 . 0 0 0 1}$ \\
CD14 -159 & - & - & $\mathbf{0 . 0 0 4}$ \\
TLR4 299 & - & - & - \\
TLR4 399 & - & - & - \\
\hline
\end{tabular}

OR: Odds ratio; Cl: Confidence intervals. 98 kU/L: Median Total lgE level. Significant $p$ value is shown with black boldface. in relation to the presence of $\mathrm{C}$ and $\mathrm{T}$ alleles. In contrast to the low log IgE levels in patients bearing $C$ alleles, patients bearing $\mathrm{T}$ alleles showed high IgE levels. This result is important because it contrasts with observations in studies reporting that the $\mathrm{C}$ allele was correlated with high IgE levels and $\mathrm{T}$ allele with low IgE levels. The previously reported prevalence of the $\mathrm{CC}+\mathrm{CT}$ genotype compared to TT genotype in asthma patients with higher total IgE levels may have resulted from the level of endotoxin exposure as reported in a meta-analysis conducted by Martinez et al. [25]. In other words dominant C or TT allele homozygosity might have a protective or risk-predictive role according to the varying degrees (low or high) of endotoxin and microbial particle exposure [29]. The correlation of CD14 C-159 T genotype with the eosinophil count in asthma was also investigated. Although two previous studies reported no correlation [18,36], eosinophil counts tended to be higher in the CC genotype than in the TT, [13] and to be more common in patients with moderate and severe asthma [21]. Also in our study the correlation between the CD14 genotype and eosinophil count was not statistically significant. The relationship of the CD14 C-159 T genotype with the severity of asthma was also investigated. In some studies the $\mathrm{C}$ allele has 


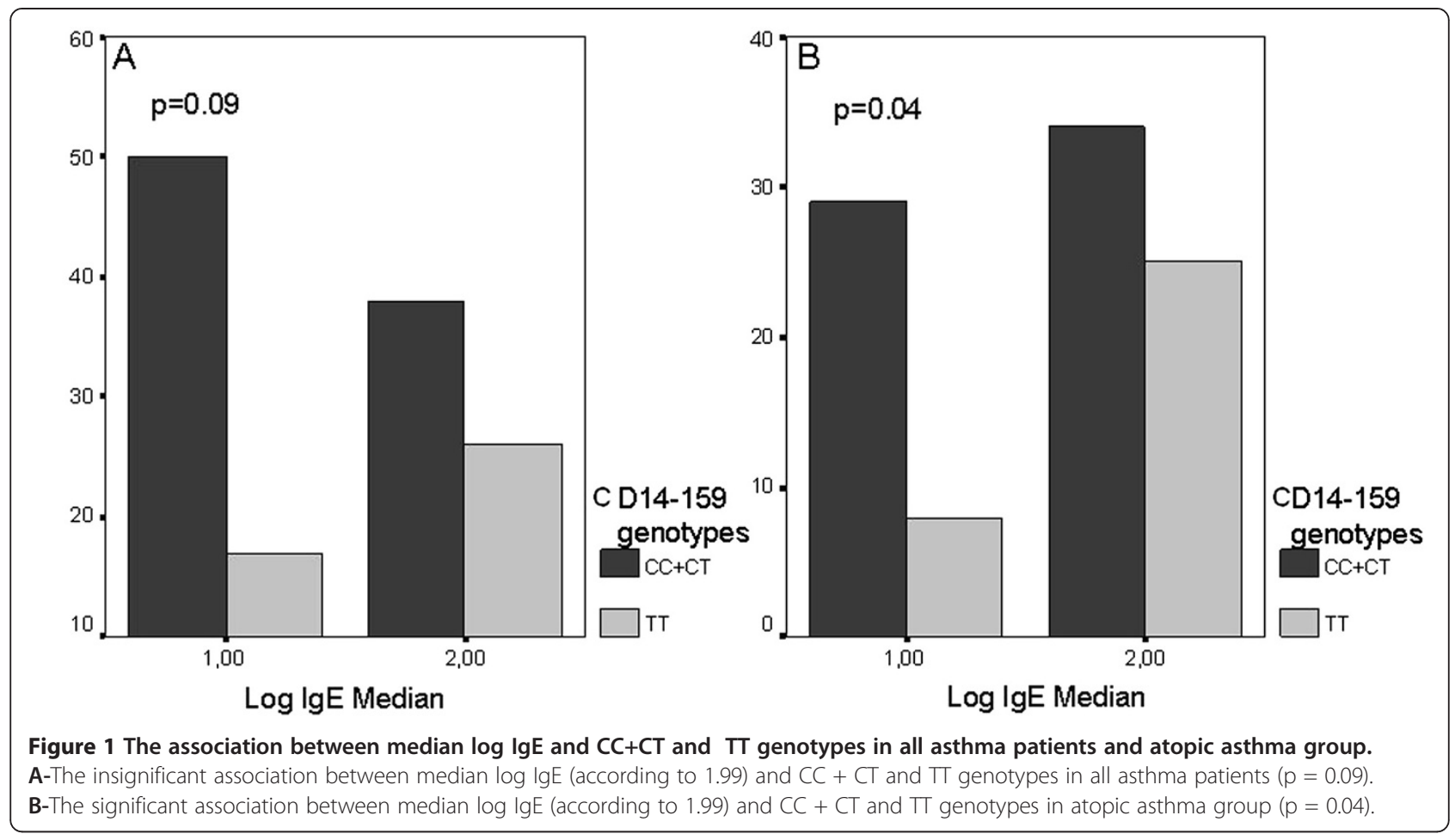

been associated with moderate-severe asthma and asthma attacks; whereas the $\mathrm{T}$ allele is associated with less severe asthma [37,38]. The CD14 C allele was found to be more common in asthma patients who were allergic to house dust. In addition, exposure of these patients to house dust caused moderate-severe asthma attacks [39]. Similarly our study found that the frequency of the $\mathrm{C}$ allele was significantly higher in the moderate and severe asthma group.

Genetic variations in TLR1, TLR2, TLR4, TLR6 and TLR10 have been associated with the development of

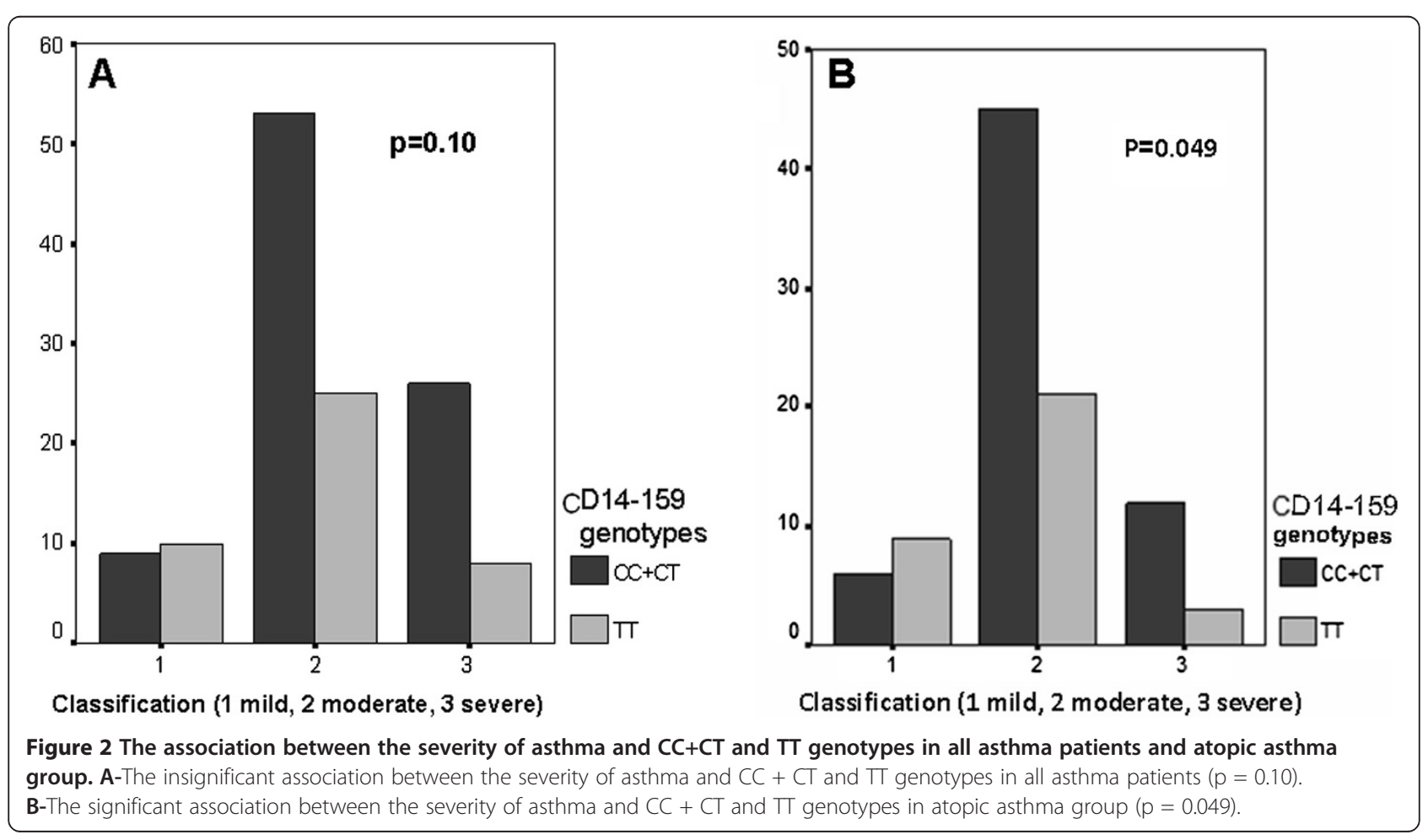


asthma [40]. The TLR4 gene (gene ID 7099) is located at chromosome 9q33.1 [41]. Polymorphisms of TLR4 genes are reportedly related to a decreased response to LPS in humans. Individuals with the Asp299Gly TLR4 polymorphism were shown to have decreased IL-12 and IL10 levels produced by mononuclear cells stimulated with LPS and a four-fold higher risk of asthma [42]. In a study conducted by Saçkesen et al. on heterozygous Turkish children the TLR4 polymorphism was reported to be related with mild asthma and may protect against severe asthma [13]. On the other hand, other studies have failed to find a correlation between common TLR4 mutations (especially Asp299Gly) and asthma or atopy $[8,41,43,44]$, the severity of asthma may have been a confounding factor in these analyses [41]. Nevertheless TLR4 polymorphism was more closely related to the moderate and severe atopic asthma group than the mild atopic asthma group For the Asp299Gly polymorphism the Asp allele was associated with mild atopic asthma and the Gly allele with moderate and severe asthma [8]. Our study did not detect a relationship between the TLR4 299 or TLR4 399 genetic variants and atopic conditions or asthma , nor did we observe a significant relationship between these genetic variants and the severity of asthma.

\section{Conclusions}

A statistically significant correlation between CD14 genotypes and total IgE levels and severity of asthma was found in our atopic patients. Total IgE levels were found to be low among patients with the $\mathrm{CC}+\mathrm{CT}$ genotype, and high among patients with the TT genotype contrary to the results of many other studies, which is therefore an important finding. This may be explained by the exposure of atopic asthma patients to varying endotoxin levels as stated in some study reports. Another important finding was that the $\mathrm{C}$ allele is a risk factor for moderate and severe asthma. Further studies will allow for the gathering of more detailed information.

\section{Abbreviations \\ TLR: Toll like receptor; LPS: Lipopolysaccharides; PAMP: Pathogen associated molecular patterns; APC: Antigen presenting cell; GINA: Global Initiative for Asthma; log: Logarithm; CC + CT: C allele; TT: T allele; FEV1: Forced expiratory volume 1.}

\section{Competing interests}

The authors declare that they have no competing interests.

\section{Authors' contributions}

FŞ performed study design, sample collection, interpretation of data and the writing manuscript. PY performed the statistical data analysis. AK, MAK, NK and KM carried out the genotyping assays. All authors read and approved the final manuscript.

\section{Acknowledgements}

This study has been supported by "Bilim Pharmaceutical Company". We thank Dr. Şükrü Aras for his assistance in the statistical analysis.

\section{Author details}

'Department of Chest Diseases, Yedikule Chest Diseases and Surgery Training and Research Hospital, Zeytinburnu/istanbul, 34760, Turkey. ${ }^{2}$ Department of Medical Genetics, Yeditepe University School of Medicine, İstanbul, Turkey. ${ }^{3}$ Department of Medical Microbiology, Cerrahpaşa School of Medicine, Istanbul University, İstanbul, Turkey. ${ }^{4}$ Department of Biotechnology, Yeditepe Univesity Institute of Science, İstanbul, Turkey.

Received: 25 June 2013 Accepted: 3 February 2014

Published: 13 February 2014

\section{References}

1. Holloway JW, Yang IA, Holgate ST: Genetics of allergic disease. J Allergy Clin Immunol 2010, 125(2 Suppl 2):S81-94.

2. Strachan DP: Hay fever, hygiene, and householdsize. BMJ 1989, 299 (6710):1259-1260.

3. Janeway CA, Travers P, Walport M, Shlomchik M: Immunobiology: the immune system in health and disease. New York: Churchill Livingstone; 2005.

4. Medzhitov R, Janeway CA Jr: Innate immunity: the virtues of a nonclonal system of recognition. Cell 1997, 91(3):295-298.

5. Banchereau J, Steinman RM: Dendritic cells and the control of immunity. Nature 1998, 392(6673):245-252.

6. Rescigno M, Granucci F, Ricciardi-Castagnoli P: Molecular events of bacterial-induced maturation of dendritic cells. J Clin Immunol 2000, 20(3):161-166.

7. Lachheb J, Dhifallah IB, Chelbi H, Hamzaoui K, Hamzaoui A: Toll-like receptors and CD14 genes polymorphisms and susceptibility to asthma in Tunisian children. Tissue Antigens 2008, 71(5):417-25.

8. Hussein YM, Awad HA, Shalaby SM, Ali AS, Alzahrani SS: Toll-like receptor 2 and Toll-like receptor 4 polymorphisms and susceptibility to asthma and allergic rhinitis: a case-control analysis. Cell Immunol 2012, 274(1-2):34-38.

9. Smit LA, Siroux V, Bouzigon E, Oryszczyn MP, Lathrop M, Demenais F, Kauffmann F: Epidemiological Study on the Genetics and Environment of Asthma, Bronchial Hyperresponsiveness, and Atopy (EGEA) Cooperative Group: CD14 and toll-like receptor gene polymorphisms, country living, and asthma in adults. Am J Respir Crit Care Med 2009, 179(5):363-8.

10. Foster SL, Medzhitov R: Gene-specific control of the TLR-induced inflammatory response. Clin Immunol 2009, 130(1):7-15.

11. Arbour NC, Lorenz E, Schutte BC, Zabner J, Kline JN, Jones M, Frees K, Watt JL, Schwartz DA: TLR4 mutations are associated with endotoxin hyporesponsiveness in humans. Nat Genet 2000, 25(2):187-191.

12. Baldini M, Lohman IC, Halonen M, Erickson RP, Holt PG, Martinez FD: A polymorphism in the $5^{\prime}$ flanking region of the CD14 gene is associated with circulating soluble CD14 levels and with total serum Immunoglobulin E. Am J Respir Cell Mol Biol 1999, 20(5):976-983.

13. Saçkesen C, Karaaslan C, Keskin O, Tokol N, Tahan F, Civelek E, Soyer OU, Adalioglu G, Tuncer A, Birben E, Oner C, Kalayci O: The effect of polymorphisms at the CD14 promoter and the TLR4 gene on asthma phenotypes in Turkish children with asthma. Allergy 2005, 60(12):1485-1492.

14. Tal G, Mandelberg A, Dalal I, Cesar K, Somekh E, Tal A, Oron A, Itskovich S, Ballin A, Houri S, Beigelman A, Lider O, Rechavi G, Amariglio N: Association between common toll-like receptor 4 mutations and severe respiratory syncytial virus disease. J Infect Dis 2004, 189(11):2057-2063.

15. Zhao L, Bracken MB: Association of CD14-260 (-159) C > T and asthma: a systematic review and meta-analysis. BMC Med Genet 2011, 12:93. doi:10.1186/1471-2350-12-93.

16. Global Initiative for Asthma (GINA): Global strategy for asthma management and prevention; 2012. www.ginasthma.org.

17. Koppelman GH, Reijmerink NE, Colin Stine O, Howard TD, Whittaker PA, Meyers DA, Postma DS, Bleecker ER: Association of a promoter polymorphism of the CD14 gene and atopy. Am J Respir Crit Care Med 2001, 163(4):965-969.

18. Marsh DG, Neely JD, Breazeale DR, Ghosh B, Freidhoff LR, Ehrlich-Kautzky E, Schou C, Krishnaswamy G, Beaty TH: Linkage analysis of IL4 and other chromosome 5q31.1 markers and total serum immunoglobulin E concentrations. Science 1994, 264(5162):1152-1156.

19. LeVan TD, Bloom JW, Bailey TJ, Karp CL, Halonen M, Martinez FD, et al: A common single nucleotide polymorphism in the CD14 promoter decreases the affinity of Sp protein binding and enhances transcriptional activity. J Immunol 2001, 167:5838-5844. 
20. Kabesch M, Hasemann K, Schickinger V, Tzotcheva I, Bohnert A, Carr D, et al: A promoter polymorphism in the CD14 gene is associated with elevated levels of soluble CD14 but not with IgE or atopic diseases. Allergy 2004, 59:520-525.

21. O'Donnell AR, Toelle BG, Marks GB, Hayden CM, Laing IA, Peat JK, Goldblatt J, Le Souëf PN: Age-specifi c relationship between CD14 and atopy in a cohort assessed from age 8 to 25 years. Am J Respir Crit Care Med 2004, 169(5):615-622.

22. Zhang Y, Tian C, Zhang J, Li X, Wan H, He C, Guo L, Meilang Q, Peng C, Duo L, Huang J, Fan $\mathrm{H}$ : The $-159 \mathrm{C} / \mathrm{T}$ polymorphism in the CD14 gene and the risk of asthma: a meta-analysis. Immunogenetics 2011, 63(1):23-32.

23. Bucková D, Hollá LI, Znojil V, Vasků A: Polymorphisms of the CD14 gene and atopic phenotypes in Czech patients with IgE mediated allergy. J Hum Genet 2006, 51(11):977-983.

24. Tan CY, Chen YL, Wu LS, Liu CF, Chang WT, Wang JY: Association of CD14 promoter polymorphisms and soluble CD14 levels in mite allergen sensitization of children in Taiwan. J Hum Genet 2006, 51(1):59-67.

25. Martinez FD: CD14, endotoxin, and asthma risk: actions and interactions. Proc Am Thorac Soc 2007, 4(3):221-225.

26. Simpson A, John SL, Jury F, Niven R, Woodcock A, Ollier WE, Custovic A: Endotoxin exposure, CD14, and allergic disease: an interaction between genes and the environment. Am J Respir Crit Care Med 2006, 174(4):386-392.

27. Williams LK, McPhee RA, Ownby DR, Peterson EL, James M, Zoratti EM, Johnson CC: Gene-environment interactions with CD14 C-260 T and their relationship to total serum IgE levels in adults. J Allergy Clin Immunol 2006, 118(4):851-857.

28. Vercelli D: Learning from discrepancies: CD14 polymorphisms, atopy and the endotoxin switch. Clin Exp Allergy 2003, 33(2):153-155.

29. Han D, She W, Zhang L: Association of the CD14 gene polymorphism C-159 T with allergic rhinitis. Am J Rhinol Allergy 2010, 24(1):e1-3. doi:10.2500/ajra.2010.24.3411.

30. Sharma M, Batra J, Mabalirajan U, Goswami S, Ganguly D, Lahkar B, Bhatia NK, Kumar A, Ghosh B: Suggestive evidence of association of C-159 T functional polymorphism of the CD14 gene with atopic asthma in northern and northwestern Indian populations. Immunogenetics 2004, 56(7):544-547.

31. Heinzmann A, Dietrich H, Jerkic SP, Kurz T, Deichmann KA: Promoter polymorphisms of the CD14 gene are not associated with bronchial asthma in Caucasian children. Eur J Immunogenet 2003, 30(5):345-348.

32. Liang XH, Cheung W, Heng CK, Liu JJ, Li CW, Lim B, de Wang Y: CD14 promoter polymorphisms have no functional significance and are not associated with atopic phenotypes. Pharmacogenet Genomics 2006, 16(4):229-236.

33. Sengler C, Haider A, Sommerfeld C, Lau S, Baldini M, Martinez F, Wahn U, Nickel R: German multicenter allergy study group. Evaluation of the CD14 C-159 T polymorphism in the German multicenter allergy study cohort. Clin Exp Allergy 2003, 33(2):166-169.

34. Baççioğlu Kavut A, Kalpaklioğlu F, Birben E, Ayaslioğlu E: Association between tuberculosis and atopy: role of the CD14-159C/T polymorphism. J Investig Allergol Clin Immunol 2012, 22(3):201-7.

35. Yazdani N, Amoli MM, Naraghi M, Mersaghian A, Firouzi F, Sayyahpour F, Mokhtari Z: Association between the functional polymorphism C-159 T in the CD14 promoter gene and nasal polyposis: potential role in asthma. J Investig Allergol Clin Immunol 2012, 22(6):406-411.

36. Keskin O, Birben E, Sackesen C, Soyer OU, Alyamac E, Karaaslan C, Tokol N, Ercan H, Kalayci O: The effect of CD14-C159T genotypes on the cytokine response to endotoxin by peripheral blood mononuclear cells from asthmatic children. Ann Allergy Asthma Immunol 2006, 97(3):321-328.

37. Zambelli-Weiner A, Ehrlich E, Stockton ML, Grant AV, Zhang S, Levett PN, Beaty TH, Barnes KC: Evaluation of CD14/-260 polymorphism and house dust endotoxin exposure in the Barbados asthma genetics study. J Allergy Clin Immunol 2005, 115(6):1203-1209.

38. Martin AC, Laing IA, Khoo SK, Zhang G, Rueter K, Teoh L, Taheri S, Hayden CM, Geelhoed GC, Goldblatt J, LeSouëf PN: Acute asthma in children. Relationship among CD14 and CC16 genotypes, plasma levels, and severity. Am J Respir Crit Care Med 2006, 173(6):617-622

39. Kowal K, Bodzenta-Lukaszyk A, Pampuch A, Szmitkowski M, Zukowski S, Donati MB, lacoviello L: Analysis of $-6754 \mathrm{~g} / 5 \mathrm{G}$ SERPINE1 and C-159 T CD14 polymorphisms in house dust mite-allergic asthma patients. J Investig Allergol Clin Immunol 2008, 18(4):284-292.

40. Nilsson D, Andiappan AK, Halldén C, De Yun W, Säll T, Tim CF, Cardell LO: Toll-like receptor gene polymorphisms are associated with allergic rhinitis: a case control study. BMC Med Genet 2012, 13:66.
41. Zhang Q, Qian FH, Zhou LF, Wei GZ, Jin GF, Bai JL, Yin KS: Polymorphisms in toll-like receptor 4 gene are associated with asthma severity but not susceptibility in a Chinese Han population. J Investig Allergol Clin Immunol 2011, 21(5):370-377.

42. Fagerås Böttcher $M$, Hmani-Aifa $M$, Lindström A, Jenmalm MC, Mai XM, Nilsson L, Zdolsek HA, Björkstén B, Söderkvist P, Vaarala O: A TLR4 polymorphism is associated with asthma and reduced lipopolysaccharideinduced interleukin- 12(p70) responses in Swedish children. J Allergy Clin Immunol 2004, 114(3):561-567.

43. Raby BA, Klimecki WT, Laprise C, Renaud Y, Faith J, Lemire M, Greenwood C, Weiland KM, Lange C, Palmer LJ, Lazarus R, Vercelli D, Kwiatkowski DJ, Silverman EK, Martinez FD, Hudson TJ, Weiss ST: Polymorphisms in toll-like receptor 4 are not associated with asthma or atopy-related phenotypes. Am J Respir Crit Care Med 2002, 166(11):1449-1456.

44. Yang IA, Barton SJ, Rorke S, Cakebread JA, Keith TP, Clough JB, Holgate ST, Holloway JW: Toll-like receptor 4 polymorphism and severity of atopy in asthmatics. Genes Immun 2004, 5(1):41-45.

doi:10.1186/1471-2466-14-20

Cite this article as: Şahin et al:: The effect of CD14 and TLR4 gene polimorphisms on asthma phenotypes in adult Turkish asthma patients: a genetic study. BMC Pulmonary Medicine 2014 14:20.

\section{Submit your next manuscript to BioMed Central and take full advantage of:}

- Convenient online submission

- Thorough peer review

- No space constraints or color figure charges

- Immediate publication on acceptance

- Inclusion in PubMed, CAS, Scopus and Google Scholar

- Research which is freely available for redistribution

Submit your manuscript at www.biomedcentral.com/submit
C Biomed Central 